\title{
Investigation of the effects of oleuropein rich diet on rat enteric bacterial flora
}

\author{
Kiraz $\mathrm{A}^{1}$, Simsek $\mathrm{T}^{2}$, Tekin $\mathrm{SZ}^{1}$, Elmas $\mathrm{S}^{3}$, Tekin $\mathrm{M}^{4}$, Sahin $\mathrm{H}^{2}$, Altinisik $\mathrm{HB}^{2}$, Pala $\mathrm{C}^{5}$ \\ Canakkale Onsekiz Mart University, Faculty of Medicine, Department of Medical Microbiology, \\ Canakkale, Turkey. draslikiraz@gmail.com
}

\begin{abstract}
OBJECTIVES AND BACKGROUND: Oleuropein is a phenolic compound of olive leaves. Enteric bacterial flora is very important for human health and diet is a directly affecting factor of enteric bacterial flora composition. In this study, it was hypothesized that oleuropein could reduce total aerobic bacterial count in rat caecal flora. METHODS: Twenty adult, male, Wistar albino rats were randomly divided into two groups. Group $C(n=10)$ was fed with standard rat chow and water for 30 days. Group $O(n=10)$ received olive leaf extract $20 \mathrm{mg} / \mathrm{kg} / \mathrm{day}$ by intragastric gavage in addition to standard rat chow and water for 30 days. One gram of caecal content was collected from each rat and then consecutive 10-fold serial dilutions were prepared with a final concentration of $10^{-8}$. Then $0.1 \mathrm{ml}$ of each dilution were spread onto the surfaces of Plate Count Agar and Violet Red Bile Glucose Agar to enumerate the aerobic enteric bacteria.

RESULTS: Total aerobic bacterial counts of Group O were significantly lower than of Group C in all agar plates inoculated with ceacal samples for every dilution $(p<0.05)$.

CONCLUSION: Adding oleuropein to enteral feeding solutions of critically ill patients may be adventageous in the presence of clinical conditions predisposing to bacterial translocation by reducing enteric bacterial counts (Tab. 1, Ref. 32). Text in PDF www.elis.sk.

KEY WORDS: enteric bacteria, intensive care, oleuropein, rat.
\end{abstract}

\section{Introduction}

Oleuropein is the main constituent of the leaves and olive drupes of Olea europaea and known as a rich source of polyphenols (1). Olive leaf (Olea europaea L.) has been used traditionally in Mediterranean countries, particularly as an antimicrobial and cardioprotective agent (2). Phenolic compounds such as oleuropein, have beneficial health effects with antioxidant, anti-inflammatory properties. These compounds are mostly concentrated in the leaves of olive plant (3). Oleuropein is rapidly absorbed after oral administration, with maximum plasma concentration occurring in two hours (1). It is reported in in vitro studies that oleuropein is

${ }^{1}$ Canakkale Onsekiz Mart University, Faculty of Medicine, Department of Medical Microbiology, Canakkale, Turkey, ${ }^{2}$ Canakkale Onsekiz Mart University, Faculty of Medicine, Department of Anesthesiology and Reanimation, Canakkale, Turkey, ${ }^{3}$ Canakkale Onsekiz Mart University, Experimental Research Application and Research Center, Canakkale, Turkey, ${ }^{4}$ Canakkale Onsekiz Mart University, Faculty of Medicine, Department of Family Medicine, Canakkale, Turkey, and ${ }^{5}$ Canakkale Onsekiz Mart University, Faculty of Engineering, Department of Food Engineering, Canakkale, Turkey

Address for correspondence: A. Kiraz, MD, Canakkale Onsekiz Mart University, Faculty of Medicine, Department of Medical Microbiology, Terzioglu Yerleskesi, 17100 Canakkale, Turkey.

Phone: +90.5376891404, Fax: +90.286.2180516

Acknowledgement: This study was presented as an oral presentation at the 7th European Congress of Pharmacology, 26-30 June, 2016 in Istanbul, Turkey. considered to have antimicrobial activity against gram-positive and gram-negative bacteria (4).

Enteric bacterial flora is essential for the health of the host and composed of about 100 trillion bacteria. Enteric bacterial flora has a very important role in the development and homeostasis of immune cells and protection of the host from infectious diseases. Although it is stable over time, several factors including diet, lifestyle, age, probiotic and antibiotic use, infections, and chronic conditions can alter the diversity and abundance of enteric bacterial flora (5). Food is a directly affecting factor on enteric bacterial flora composition (6). Oleuropein and other biophenols decrease pathogenic bacteria and regulate enteric bacterial flora $(7,8)$. Bacterial translocation (BT) is defined as enteric bacterial presence in various organs by spreading through the epithelial mucosa (9). Although it is not clear whether the process of BT involves live bacteria or bacterial products, it is definitely known that the increase of enteric bacterial count (bacterial overgrowth) presents a risk for BT (10). BT is frequently discountered in critically ill patients and may lead to the development of sepsis, multiple organ dysfunction syndrome and death (11). In a previous experimental study, it was reported that olive leaf extract reduced the incidence of BT in obstructive jaundiced rats (12). Previous studies in critically ill patients have reported that early enteral feeding decreases mortality rates and decreases the risk of complications (13-15).

In this experimental study, we hypothesized that oleuropein obtained from olive leaf could reduce the total aerobic bacterial count in rat caecal flora. 
Tab. 1. Total aerobic bacterial counts in two groups (CFU/g).

\begin{tabular}{ccc}
\hline \multirow{2}{*}{ Dilutions of Ceacal Samples } & Group O & Group C \\
\cline { 2 - 3 } & PCA/VRBG Mean $(\mathrm{min}-\mathrm{max})$ & PCA/VRBG Mean $(\mathrm{min}-\mathrm{max})$ \\
\hline $10^{-1}$ & $62.1 \times 10^{4}\left(55 \times 10^{4}-69 \times 10^{4}\right)^{*} / 32.5 \times 10^{4}\left(26 \times 10^{4}-38 \times 10^{4}\right)^{*}$ & $78.4 \times 10^{6}\left(72 \times 10^{6}-86 \times 10^{6}\right) / 50.9 \times 10^{6}\left(46 \times 10^{6}-55 \times 10^{6}\right)$ \\
\hline $10^{-2}$ & $59.1 \times 10^{4}\left(51 \times 10^{4}-74 \times 10^{4}\right)^{*} / 28.5 \times 10^{4}\left(21 \times 10^{4}-35 \times 10^{4}\right)^{*}$ & $72.8 \times 10^{6}\left(66 \times 10^{6}-79 \times 10^{6}\right) / 45.8 \times 10^{6}\left(42 \times 10^{6}-49 \times 10^{6}\right)$ \\
\hline $10^{-3}$ & $53.1 \times 10^{4}\left(45 \times 10^{4}-64 \times 10^{4}\right)^{*} / 24.8 \times 10^{4}\left(19 \times 10^{4}-29 \times 10^{4}\right)^{*}$ & $66.8 \times 10^{6}\left(62 \times 10^{6}-74 \times 10^{6}\right) / 40.6 \times 10^{6}\left(37 \times 10^{6}-44 \times 10^{6}\right)$ \\
\hline $10^{-4}$ & $46.8 \times 10^{4}\left(40 \times 10^{4}-57 \times 10^{4}\right)^{*} / 21 \times 10^{4}\left(17 \times 10^{4}-24 \times 10^{4}\right)^{*}$ & $60.8 \times 10^{6}\left(54 \times 10^{6}-68 \times 10^{6}\right) / 34.6 \times 10^{6}\left(30 \times 10^{6}-39 \times 10^{6}\right)$ \\
\hline $10^{-5}$ & $37.6 \times 10^{4}\left(22 \times 10^{4}-52 \times 10^{4}\right)^{*} / 16.4 \times 10^{4}\left(13 \times 10^{4}-19 \times 10^{4}\right)^{*}$ & $54.4 \times 10^{6}\left(49 \times 10^{6}-61 \times 10^{6}\right) / 29.1 \times 10^{6}\left(24 \times 10^{6}-34 \times 10^{6}\right)$ \\
\hline $10^{-6}$ & $31.4 \times 10^{4}\left(17 \times 10^{4}-46 \times 10^{4}\right)^{*} / 11.9 \times 10^{4}\left(8 \times 10^{4}-15 \times 10^{4}\right)^{*}$ & $48.1 \times 10^{6}\left(43 \times 10^{6}-56 \times 10^{6}\right) / 22.7 \times 10^{6}\left(19 \times 10^{6}-27 \times 10^{6}\right)$ \\
\hline $10^{-7}$ & $26 \times 10^{4}\left(12 \times 10^{4}-42 \times 10^{4}\right)^{*} / 8.7 \times 10^{4}\left(5 \times 10^{4}-12 \times 10^{4}\right)^{*}$ & $40.8 \times 10^{6}\left(34 \times 10^{6}-49 \times 10^{6}\right) / 17.3 \times 10^{6}\left(13 \times 10^{6}-22 \times 10^{6}\right)$ \\
\hline $10^{-8}$ & $16.7 \times 10^{4}\left(3 \times 10^{4}-31 \times 10^{4}\right)^{*} / 3.8 \times 10^{4}\left(1 \times 10^{4}-8 \times 10^{4}\right)^{*}$ & $33.8 \times 10^{6}\left(29 \times 10^{6}-41 \times 10^{6}\right) / 11.1 \times 10^{6}\left(6 \times 10^{6}-17 \times 10^{6}\right)$ \\
\hline PCA - Plate Count Agar, VRBG: Violet Red Bile Glucose Agar, CFU/g - colony forming unit/gram, * - with Mann-Whitney U test p < 0.05
\end{tabular}

\section{Materials and methods}

After ethical approval of Çanakkale Onsekiz Mart University, Local Ethics Committee for Animal Experiments (decision number: 2015/08-25), twenty adult, male Wistar albino rats with weight ranging from 250-350 grams were housed in a clean facility, 2 per cage under a 12:12 h light/dark cycle with a constant room temperature of $22 \pm 1{ }^{\circ} \mathrm{C}$. Standard rat chow and water was provided ad libitum. Rats were randomly divided into two groups:

Group C $(\mathrm{n}=10)$ was the control group and rats were fed with standard rat chow and water for 30 days.

Group $O(\mathrm{n}=10)$ was the study group. Rats received olive leaf extract $20 \mathrm{mg} / \mathrm{kg} /$ day by intragastric gavage in addition to standard rat chow and water for 30 days.

Olive leaves were harvested from olive tree (Olea europaea var Ladolia) grown in Gökçeada (Imbros), Çanakkale, Turkey. Leaves were dried at $80^{\circ} \mathrm{C}$ for 4 hours. Dried leaves were ground using Delonghi coffee grinder KG49 and then filtered using 850 mm laboratory sieve. Olive leaf powder was extracted 1:5 (w:v) with hot water in water bath (Memmert WNB 10, Germany) at $80{ }^{\circ} \mathrm{C}$ for $10 \mathrm{~min}$. The mixture was filtered using cotton fabric and transferred to falcone tubes $(15 \mathrm{~mL})$. Olive leaf extracts were stored at $-20^{\circ} \mathrm{C}$ to prevent degradation of oleuropein during the experimental procedure.

At the end of the study period all rats were sacrificed with high dose anesthesia by intramuscular $80 \mathrm{mg} / \mathrm{kg}$ ketamine (Ketalar, Pfizer, Turkey) and 10 mg/kg xylazine HCL (Rompun, Bayer, Turkey). Laparotomy was performed and one gram of caecal content collected from each rat under sterile conditions. Sterile physiological saline solution of $9 \mathrm{~mL}$ was added to all ceacal contents. Subsequently, they were homogenized by using a stomacher (Interscience-Bag Maxer 400) for 1-2 minutes and consecutive 10 -fold serial dilutions were prepared with a final concentration of $10^{-8}$. Then $0.1 \mathrm{~mL}$ of each dilution were spread onto the surfaces of Plate Count Agar (Oxoid, UK) (PCA) and Violet Red Bile Glucose Agar (Oxoid, UK) (VRBG) to determine the total number of aerobic enteric bacteria. After incubation at $37^{\circ} \mathrm{C}$ for 48 hours, bacterial counts from all plates were recorded as CFU/g (colony forming unit/gram).

\section{Statistical analysis}

The statistical analyses were performed using the SPSS 16.0 for Windows. Group comparisons were performed by the MannWhitney U test corrected with Bonferroni and $\mathrm{p}<0.05$ were accepted to be statistically significant.

\section{Results}

Total aerobic bacterial counts of Group O were significantly lower than Group C in both PCA and VRBG agar plates inoculated with ceacal samples for every dilution $(\mathrm{p}<0.05)$ (Tab. 1).

\section{Discussion}

Intestinal microbiota is estimated to comprise over $10^{14}$ bacteria from more than 1000 species (16). The composition of the human intestinal microbiota has an important role in health (17). The majority of mammalian intestinal microbiota is constituted of four bacterial phyla and among these, the Bacteroidetes and the Firmicutes are two predominating phyla (16). The concentration of aerobic flora is much lower and Escherichia coli species are dominant among the gram-negative bacilli. Among the aerobic gram-positive cocci, the enterococci, staphylococci and streptococci are dominant (10). Most of the members are obligate anaerobes and many of them have not been cultivated. The rat intestinal microbiota is similar to human intestinal microbiota in terms of bacterial content, therefore the rat is an ideal model to study the microbial composition. The composition of intestinal microbiota is influenced by host environment and diet is a very important affecting factor (16). Currently, the modification of intestinal microbiota has become an important objective of researches (17).

Normally, the intestines provide a barrier to invasion by pathologic microorganisms. This barrier function impairs during critical illnesses and microbial compounds may easily cross the mucosa, reach to mesenteric lymph nodes, portal blood system and other organs. It refers to BT and is a very life-threatening clinical tableu $(9,10)$. It is known that critically ill patients are predisposed to alterations in enteric bacterial flora that lead to complications. The disruption of the balance of enteric bacterial flora alter defense mechanisms and lead to overgrowth of potentially pathogenic 
bacteria such as Salmonella, Yersinia and Pseudomonas aeruginosa (18). Normal enteral feeding is a factor affecting intestinal functions positively such as mucosal mass maintenance, cellular proliferation and brush border enzyme production. Considering that most endogenous infections are caused by aerobic flora, provision of enteral nutrition maintains the predominant, anaerobic flora of the intestines (10).

Today, there is an increasing interest in medicinal plant extracts that are easily attainable. Olive tree leaf is one of these plant extracts and has been used traditionally in Mediterranean countries. Olive leaf contains triterpenes, flavonoids, chalcones and tannins. Among these, oleuropein, one of the iridoide monoterpenes, is the main constituent of olive leaf and is responsible for its pharmacological effects (2). The proven effects of oleuropein such as antioxidant, antiatherosclerotic, hypoglycemic, antihypertensive, anti-inflammatory and antimicrobial were reported in various experimental studies (19-22). In this study, it was found that intragastric administration of oleuropein during 30 days reduced the total aerobic bacterial count in rat enteric bacterial flora.

Malnutrition is a very important issue in critically ill patients and delays in enteral feeding initiation are a common problem worldwide (23). Total parenteral nutrition (TPN) is widely used for critically ill patients. Various studies reported that early enteral nutrition is an improving factor over patient outcome compared with TPN (24-27). There are various studies about enteral nutrition enriched with different compounds in critically ill patients and although obtaining conflicting results, some of them reported beneficial effects $(21,28-30)$. It may be due to different patient populations, study designs, timing, dosing regimens and outcome measures evaluated. A previous study reported that in critically ill patients, enteral nutrition compared to parenteral nutrition decreased infectious complications and length of hospital stay (31). Today, it is known that mortality rates will decrease by starting enteral feeding earlier in critically ill patients (32). Overgrowth of bacteria in bowels is an important risk factor for BT and critically ill patients are more prone to develope BT $(10,11,32)$. Based on this issue, reducing enteric bacterial count may be helpful for patients with potential risk of BT.

This study has a limitation that all of the bacteria (e.g. obligate anaerobes) in the rat ceacal flora could not be cultivated with conventional culture methods we used. It could be necessary with molecular methods like $16 \mathrm{~S}$ ribosomal RNA sequencing. Additionally, the effects of oleuropein dose of $20 \mathrm{mg} / \mathrm{kg} /$ day could be seen and different doses of oleuropein were not investigated. We think that higher oleuropein doses may reduce bacterial count more and further experimental studies are needed for this issue.

In conclusion, it was thought that adding oleuropein to enteral feeding solutions of critically ill patients may be advantegeous in the presence of clinical conditions predisposing to BT by reducing enteric bacterial counts. Bioavailability of oleuropein is heterogeneous and highly dependent on various factors such as gender. Adjustment of the most beneficial dose may be found by further experimental studies with longer periods.

\section{References}

1. Andreadou I, Iliodromitis EK, Mikros E, Constantinou M, Agalias A, Magiatis AP et al. The olive constituent oleuropein exhibits anti-ischemic, antioxidative, and hypolipidemic effects in anesthetized rabbits. J Nutr 2006; 136: 2213-2219.

2. Dekanski D, Ristic S, Radonjić NV, Petronijević ND, Dekanski A, Mitrović DM. Olive leaf extract modulates cold restraint stress-induced oxidative changes in rat liver. J Serb Chem Soc 2011; 76 (9): 1207-1218.

3. de Bock M, Thorstensen EB, Derraik JG, Henderson HV, Hofman PL, Cutfield WS. Human absorption and metabolism of oleuropein and hydroxytyrosol ingested as olive (Olea europaea L.) leaf extract. Mol Nutr Food Res 2013; 57 (11): 2079-2085.

4. Çağlayan K, Güngör B, Çinar H, Avci B, Gür S, Arslan N. Effects of oleuropein on serum inflammatory cytokines and histopathological changes in rats with pancreatitis. Adv Clin Exp Med 2015; 24 (2): 213-218.

5. Singh P, Teal TK, Marsh TL, Tiedje JM, Mosci R, Jernigan K, et al. Intestinal microbial communities associated with acute enteric infections and disease recovery. Microbiome 2015; 22 (3): 45.

6. da Silva ST, dos Santos CA, Bressan J. Intestinal microbiota; relevance to obesity and modulation by prebiotics and probiotics. Nutr Hosp 2013; 28 (4): 1039-1048.

7. Bisignano G, Tomaino A, Lo Cascio R, Crisafi G, Uccella N, Saija A. On the in-vitro antimicrobial activity of oleuropein and hydroxytyrosol. J Pharm Pharmacol 1999; 51 (8): 971-974.

8. Medina E, de Castro A, Romero C, Brenes M. Comparison of the concentrations of phenolic compounds in olive oils and other plant oils: correlation with antimicrobial activity. J Agric Food Chem 2006; 54 : 4954-4961.

9. Başoğlu M, Yildirgan MI, Polat KY, Gündoğdu C, Kavak I, Çelebi S. Bacterial translocation after intraperitoneal drain in the splenectomized rats. T Klin J Med Sci 1998; 18 (3): 190-195.

10. Codner PA. Enteral nutrition in the critically ill patient. Surg Clin N Am 2012; 92: 1485-1501.

11. Puleo F, Arvanitakis M, Van Gossum A, Preiser J. Gut failure in the ICU. Semin Respir Crit Care Med 2011; 32 (5): 626-638.

12. Yildirim M, Amanvermez R, Polat C, Karadag A, Karayigit MO, Erzurumlu K. The olive leaf extract attenuates bacterial translocation and liver damage in obstructive jaundice. Bratisl Lek Listy 2014; 115 (6): 357-361.

13. Petrov MS, van Santvoort HC, Besselink MG, van der Heijden GJ, Windsor JA, Gooszen HG. Enteral nutrition and the risk of mortality and infectious complications in patients with severe acute pancreatitis: a meta-analysis of randomized trials. Arch Surg 2008; 143: 1111-1117.

14. Lewis SJ, Andersen HK, Thomas S. Early enteral nutrition within $24 \mathrm{~h}$ of intestinal surgery versus later commencement of feeding: a systematic review and meta-analysis. J Gastrointest Surg 2009; 13: 569-575.

15. Wang G, Wen J, Xu L, Zhou S, Gong M, Wen P et al. Effect of enteral nutrition and ecoimmunonutrition on bacterial translocation and cytokine production in patients with severe acute pancreatitis. J Surg Res 2013; 183 (2): 592-597.

16. Lecomte V, Kaakoush NO, Maloney CA, Raipuria M, Huinao KD, Mitchell HM et al. Changes in gut microbiota in rats fed a high fat diet correlate with obesity-associated metabolic parameters. PLoS One 2015; 10 (5): e0126931. 
17. Montesi A, García-Albiach R, Pozuelo MJ, Pintado C, Goñi I, Rotger R. Molecular and microbiological analysis of caecal microbiota in rats fed with diets supplemented either with prebiotics or probiotics. Int J Food Microbiol 2005; 98 (3): 281-289.

18. Singhi SC, Kumar S. Probiotics in critically ill children. F1000Res 2016; 29: 5 .

19. EI SN, Karakaya S. Olive tree (Olea europaea) leaves: potential beneficial effects on human health. Nutr Rev 2009; 67 (11): 632-638.

20. Khalatbary AR, Zarrinjoei GR. Anti-inflammatory effect of oleuropein in experimental rat spinal cord trauma. Iran Red Crescent Med J 2012; 14 (4): 229-234.

21. Lee OH, Lee BY. Antioxidant and antimicrobial activities of individual and combined phenolics in Olea europaea leaf extract. Bioresour Technol 2010; 101 (10): 3751-3754.

22. Sudjana AN, D'Orazio C, Ryan V, Rasool N, Ng J, Islam N et al. Antimicrobial activity of commercial Olea europaea (olive) leaf extract. Int J Antimicrob Agents 2009; 33 (5): 461-463.

23. Stewart ML, Biddle M, Thomas T. Evaluation of current feeding practices in the critically ill: A retrospective chart review. Intensive Crit Care Nurs 2016; 16: 30023-30024.

24. Sax HC, Warner BW, Talamini MA, Hamilton FN, Bell RH, Fischer JE et al. Early total parenteral nutrition in acute pancreatitis: lack of beneficial effects. Am J Surg 1987; 153: 117-124.

25. Al-Omran M, Albalawi ZH, Tashkandi MF, Al-Ansary LA. Enteral versus parenteral nutrition for acute pancreatitis. Cochrane Database Syst Rev 2010; CD002837.
26. Quan H, Wang X, Guo C. A meta-analysis of enteral nutrition and total parenteral nutrition in patients with acute pancreatitis. Gastroenterol Res Pract 2011; 698248.

27. Cao Y, Xu Y, Lu T, Gao F, Mo Z. Meta-analysis of enteral nutrition versus total parenteral nutrition in patients with severe acute pancreatitis. Ann Nutr Metab 2008; 53: 268-275.

28. Lubbers T, Kox M, de Haan JJ, Greve JW, Pompe JC, Ramakers BP et al. Continuous administration of enteral lipid- and protein-rich nutrition limits inflammation in a human endotoxemia model. Crit Care Med 2013; 41 (5): 1258-1265.

29. Roosevelt H. Should immune-enhancing formulations be used for patients with acute respiratory distress syndrome? Nutr Clin Pract 2016; 31: 451.

30. Van Arsdall M, Haque I, Liu Y, Rhoads JM. Is there a role for the enteral administration of serum-derived immunoglobulins in human gastrointestinal disease and pediatric critical care nutrition? Adv Nutr 2016; 7 (3): 535-543.

31. Elke G, van Zanten AR, Lemieux M, McCall M, Jeejeebhoy KN, Kott $\mathbf{M}$ et al. Enteral versus parenteral nutrition in critically ill patients: an updated systematic review and meta-analysis of randomized controlled trials. Crit Care 2016; 20 (1): 117.

32. Sertaridou E, Papaioannou V, Kolios G, Pneumatikos I. Gut failure in critical care: old school versus new school. Ann Gastroenterol 2015; 28 (3): 309-322.

Received August 15, 2016. Accepted September 17, 2016. 